\title{
Inflation Dynamics And Economic Growth In Tanzania: A Multivariate Time Series Model
}

Nicholas M. Odhiambo, University of South Africa, South Africa

\begin{abstract}
This study examines the short-run and long-run causal relationship between inflation, investment and economic growth in Tanzania. In the main, the study incorporates investment in a bivariate setting between inflation and economic growth - hence, creating a trivariate model. The study attempts to answer one critical question: Does inflation have any significant influence on economic growth and investment in Tanzania? Using the ARDL-bounds testing approach, the study finds a unidirectional causal flow from inflation to economic growth - without any feedback response. The study also finds that investment in Tanzania unambiguously causes economic growth. The results apply irrespective of whether the causality is estimated in the long run or in the short run.
\end{abstract}

Keywords: Africa; Tanzania; Inflation; Inflation; and Growth

\section{INTRODUCTION}

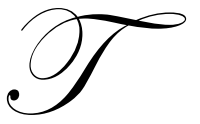

he dynamic relationship between inflation and economic growth has recently been a subject of intense debate. Some studies argue that there is a distinct and unambiguous negative relationship between inflation and economic growth. According to these studies, inflation increases the transaction and information costs; and these costs, in turn, hinder economic growth and development (see Rousseau and Wachtel, 2002). When inflation is high and persistent, economic agents find long-term planning to be difficult, because of the uncertainty about future absolute and real prices. This makes it difficult for economic agents to enter into new contracts; which, in turn, inhibits investment, resource-allocation and economic growth. Inflation also discourages savings, by making the present value of money to be higher than its future value - thereby, leading to a decrease in the quality and quantity of investment. Some of the studies whose findings directly or indirectly support a negative relationship between inflation and economic growth include Bruno and Easterly (1998), Barro (1996), Burdekin et al. (1994) and Fischer (1993). Bruno and Easterly (1998), for example, find a negative relationship between high inflation (more than 40\%) and economic growth. The authors argue that the negative relationship between high inflation and economic growth is largely due to high inflation episodes. Barro (1996), however, finds that there is a negative and significant relationship between inflation and economic growth only when inflation exceeds 20\%. Burdekin et al (1994) also find negative effects of inflation on economic growth in the countries studied - although the magnitude of these effects is much larger for the industrial countries than it is for developing countries. Fischer (1993) also argues that inflation is not good for long-term growth, however weak the evidence to the contrary may be.

Others scholars, however, argue that there is a threshold, below which a moderate increase in inflation promotes growth, but above which further increases in inflation retard economic growth. This threshold, however, differs from country to country and over time. Unfortunately, empirical studies on the relationship between inflation and economic growth in sub-Saharan African countries, which have been mired in high inflation over the years, are very scant. The majority of the previous studies on the dynamics of inflation have concentrated mainly on the determination of inflation threshold rather than on the causality between inflation and economic growth. 
To the best of our knowledge, this is the first study to rigorously examine the causal relationship between inflation and economic growth in Tanzania - using the recently developed ARDL-bounds testing approach. In order to address the omission of variable bias, which is associated with a number of previous studies, this study incorporates investment, as an intermittent variable between inflation and economic growth, in a tri-variate setting.

The motivation for including investment in the model is informed by the theoretical link between investment and economic growth on the one hand, and that of investment and inflation, on the other hand. For example, an increase in investment leads to an increase in income, which leads to more consumption - thereby, resulting in a further increase in income. This argument is based on the notion that a small increase in investment has a larger effect on income - because economic agents are likely to spend the increased income - thereby, leading to a higher GDP (see Keynes, 1936). Unlike the investment-growth relationship, the inflation-growth relationship is largely negative, especially when inflation is very high. Specifically, inflation makes the nominal values of future assets uncertain - thereby, making current investment planning more difficult. In other words, high and unpredicted inflation inhibits investment - because it discourages investors from entering into new contracts. In such cases, high inflation would not only inhibit economic growth, but could also result in a financial recession (see Hellerstein, 1997). The rest of the paper is organised as follows: Section 2 highlights the dynamics of inflation and economic growth in Tanzania. Section 3 presents the estimation techniques and the empirical results, while Section 4 concludes the study.

\section{INFLATION DYNAMICS AND ECONOMIC GROWTH IN TANZANIA}

Low inflation has been at the heart of Tanzania's monetary authorities since the country attained independence in the 1960s. In fact, the primary mission of the Bank of Tanzania (Tanzania central bank) is to maintain domestic price stability that is conducive to the attainment of macroeconomic stability and the achievement of sustainable growth. The Bank of Tanzania has the responsibility of ensuring that monetary conditions that there consistent with low and suitable inflation are established (see SADC, 2011).

Unlike some countries, Tanzanian inflation rate excludes food prices. This is because food prices are very volatile and are in most cases driven by short lived supply-side factors rather than the demand-side factors. According to the Bank of Tanzania, food prices are sometimes affected by non-monetary factors, like drought and floods, which may aggravate the overall inflation rate - irrespective of monetary policy. This was evidenced in December 2010, when the food inflation was 6.3\%, while the non-food inflation was 4.7\%. In Tanzania, inflation is considered to be a monetary phenomenon. Hence, it is controlled by influencing the growth of broad money supply i.e. (M2) - which includes currency in circulation outside banks, the total deposits held by commercial banks, excluding foreign currency deposits.

Since the 1980s, the Tanzania monetary authorities have made significant progress in containing inflation. Although Tanzania's average inflation rate remained at a double-digit level between 1980 and 1998; the rate later declined phenomenally between 1996 and 2000, with the lowest inflation rate recorded in 2000. In 2001, the rate increased slightly, but between 2001 and 2004, the rate systematically declined, with the lowest rate since the 1980s being recorded in 2004. Although the rate remained at a single-digit level between 2005 and 2007, it later increased to a double-digit level between 2008 and 2009, before it again decreased to a single digit in 2010. Figure 1 shows the trends of inflation in Tanzania between 1996 and 2010.

Unlike in the case of inflation, the Tanzania's economic growth has shown a more or less erratic trend. Although the country recorded an average GDP growth rate of about 3\% between 1991 and 2000, the GDP growth rate in 1992 was only $0.584 \%$. The rate, however, later increased significantly to $4.6 \%$ in 1996 . Between 2000 and 2002, the real GDP growth rate further increased steadily from $4.9 \%$ in 2000 , to $6 \%$ in 2001, and $7.2 \%$ in 2002 . Although the rate slightly decreased to $6.9 \%$ in 2003 , it later increased significantly to $7.8 \%$ in 2004 . Although the rate decreased somewhat between 2004 and 2006, from 7.8\% in 2004 to $7.4 \%$ in 2005 and later to $6.7 \%$ in 2006, it later increased slightly to $7.1 \%$ in 2007 and $7.4 \%$ in 2008. Even after the 2008/9 world economic and financial crisis, Tanzania's current real GDP growth is still higher than the 2000 and 2001 growth rates (see Global Finance, 2011). Figure 2 shows the trends of GDP growth rate and per capita GDP growth rate in Tanzania during the period 1996-2010. 


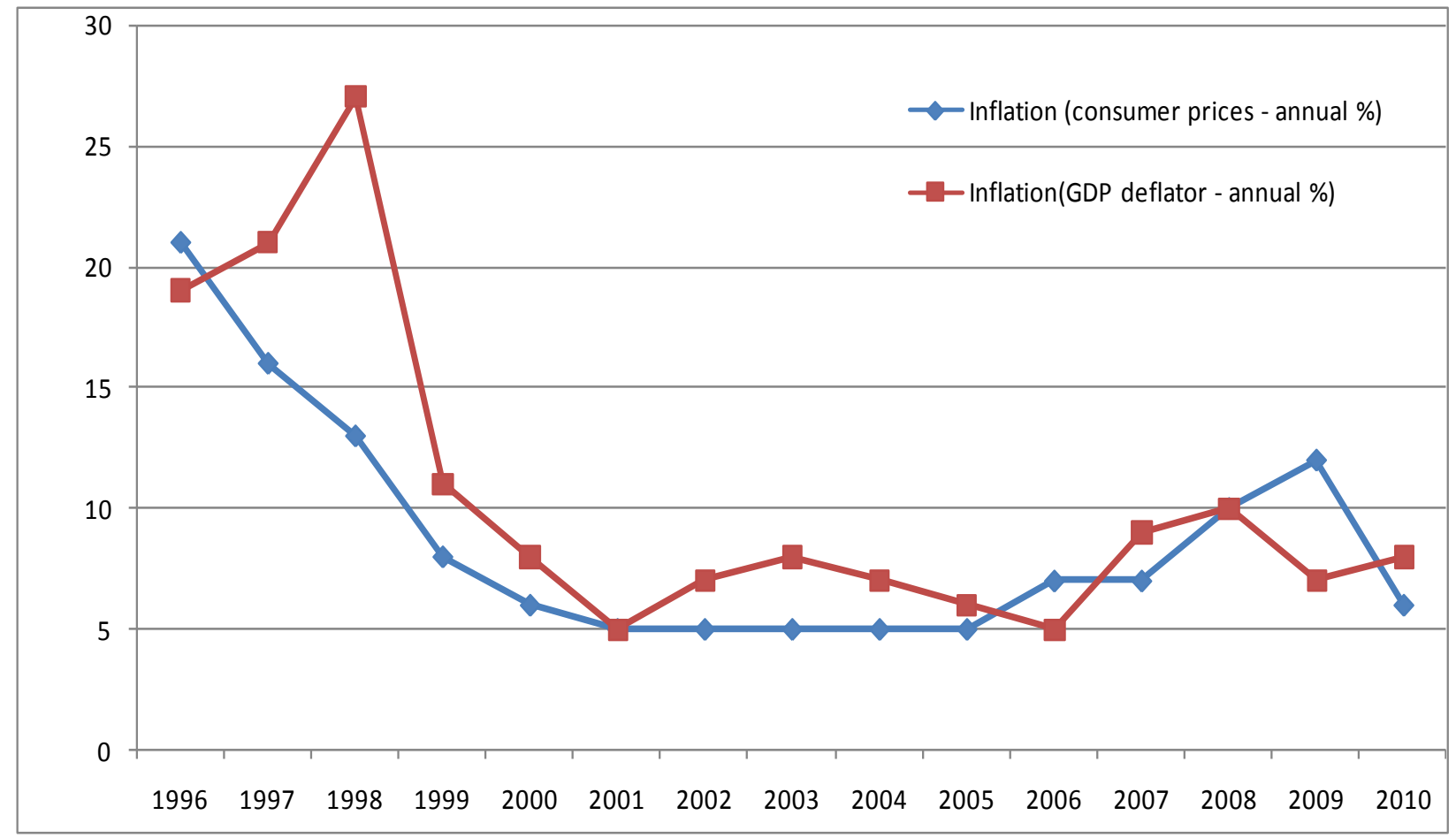

Figure 1: Trends of inflation in Tanzania during the period 1996-2010

Source: World Development Indicators (2011)

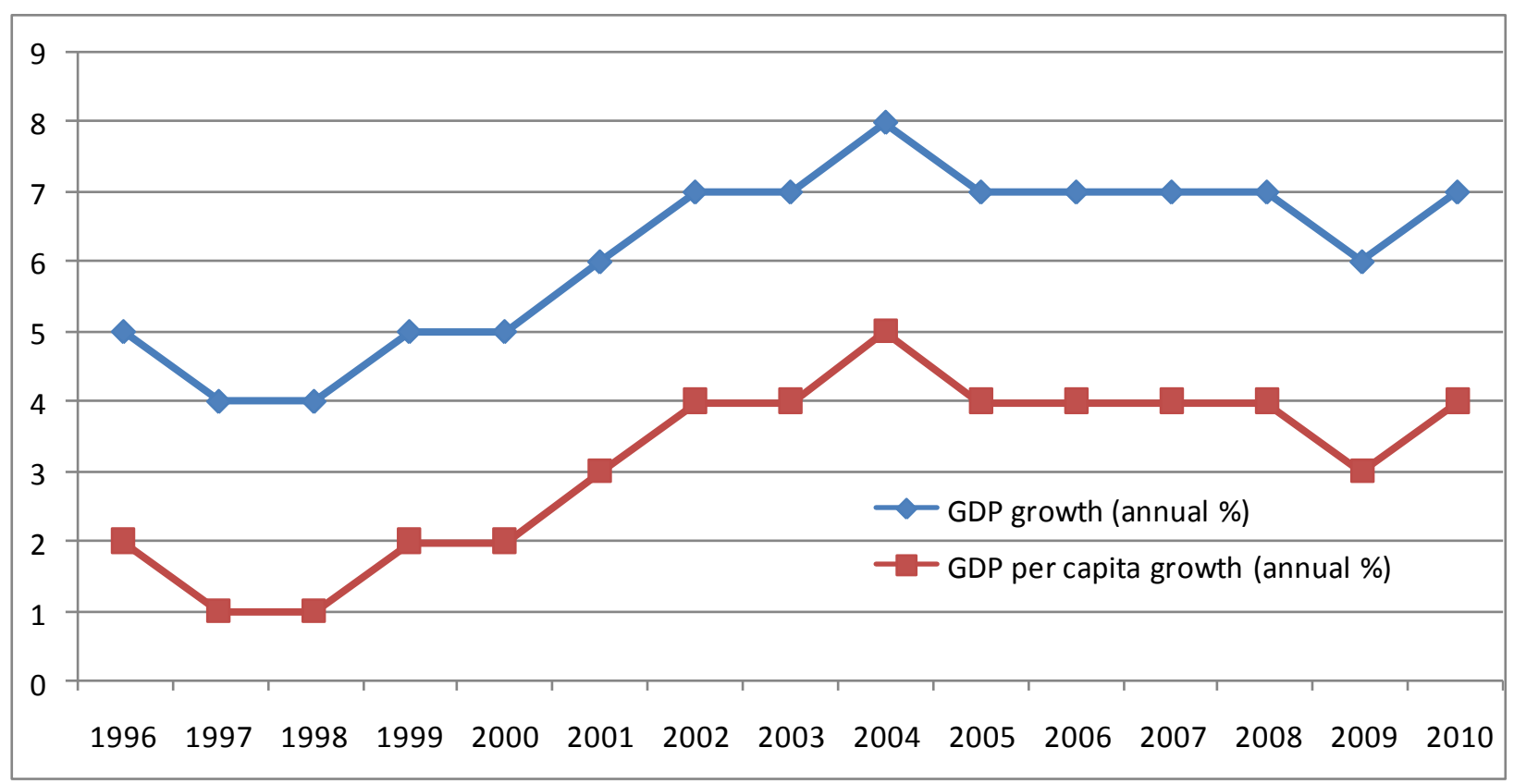

Figure 2: Trends of GDP growth rate and GDP per capita growth rate in Tanzania during the period 1996-2010 Source: World Development Indicators (2011) 


\section{ESTIMATION TECHNIQUES AND EMPIRICAL ANALYSIS}

\subsection{Cointegration - ARDL-bounds Testing Procedure}

The cointegration technique used in this study is based on the recently developed Autoregressive Distributed Lag (ARDL)-bounds testing approach by Perasan et al. (2001). The ARDL-bounds model used in this study can be expressed as follows:

$$
\begin{aligned}
& \Delta \operatorname{Iny} / N_{t}=\alpha_{0}+\sum_{i=1}^{n} \alpha_{1 i} \Delta \operatorname{Iny} / N_{t-i}+\sum_{i=0}^{n} \alpha_{2 i} \Delta \operatorname{InINF_{t-i}}+\sum_{i=0}^{n} \alpha_{3 i} \Delta \operatorname{InIN} V_{t-i}+\alpha_{4} \operatorname{Iny} / N_{t-1}+ \\
& \alpha_{5} \operatorname{InINF}_{t-1}+\alpha_{6} \operatorname{InINV_{t-1}}+\mu_{t}
\end{aligned}
$$

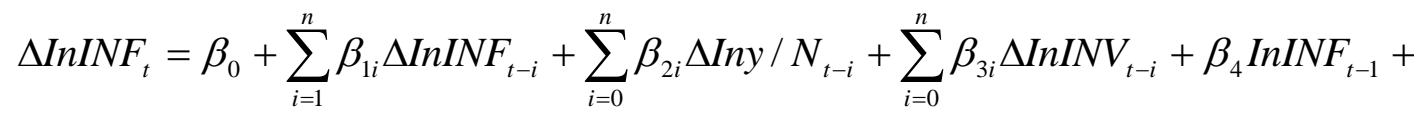

$$
\begin{aligned}
& \beta_{5} \operatorname{Iny} / N_{t-1}+\beta_{6} \operatorname{InIN} V_{t-1}+\mu_{t}
\end{aligned}
$$

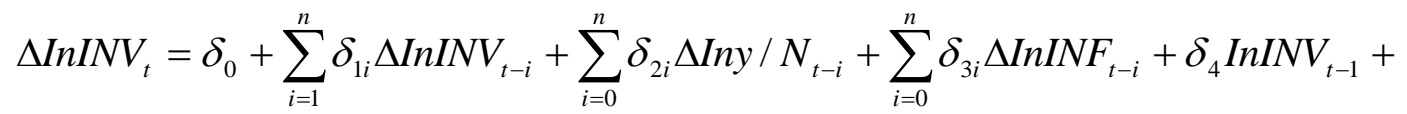

$$
\begin{aligned}
& \delta_{5} \operatorname{Iny} / N_{t-1}+\delta_{6} \operatorname{InINF}_{t-1}+\mu_{t}
\end{aligned}
$$

Where: Iny $/ \mathrm{N}=\log$ of real per capita income; InINF $=\log$ of consumer inflation; InINV $=\log$ of investment; $\mu_{\mathrm{t}}=$ white noise error term; $\Delta=$ first difference operator.

The bounds-testing procedure is based on the joint F-statistic or Wald statistic, whose asymptotic distribution is non-standard. In the bounds-testing approach, the null hypothesis of no cointegration among the variables in equations (1), (2) and (3) is tested against the alternative hypothesis that there is a cointegration among the variables under study. Two sets of critical values are reported by Pesaran and Pesaran (1997) and Pesaran et al. (2001) for any given significance level. While one set of critical values assumes that all variables included in the ARDL model are $\mathrm{I}(0)$, the other set assumes that the variables are $\mathrm{I}(1)$. When the computed test statistic exceeds the upper critical bounds value, then the Ho hypothesis is rejected. When the F-statistic is lower than the lower bounds value, then the null hypothesis of no cointegration cannot be rejected. However, when the F-statistic falls into the bounds the cointegration test becomes inconclusive.

\subsection{Granger Non-causality Test}

The Granger-causality between inflation, investment and economic growth can be examined by using the following model (see also Odhiambo, 2009a; Odhiambo, 2009b; Narayan and Smyth, 2008).

$$
\begin{aligned}
& \Delta \operatorname{Iny} / N_{t}=\alpha_{0}+\sum_{i=1}^{n} \alpha_{1 i} \Delta \operatorname{Iny} / N_{t-i}+\sum_{i=0}^{n} \alpha_{2 i} \Delta \operatorname{InINF}_{t-i}+\sum_{i=0}^{n} \alpha_{3 i} \Delta \operatorname{InIN} V_{t-i}+E C M_{t-1}+\mu_{t} . \text { (4) } \\
& \Delta \operatorname{InINF}_{t}=\beta_{0}+\sum_{i=1}^{n} \beta_{1 i} \Delta \operatorname{InINF}_{t-i}+\sum_{i=0}^{n} \beta_{2 i} \Delta \operatorname{Iny} / N_{t-i}+\sum_{i=0}^{n} \beta_{3 i} \Delta \operatorname{InIN} V_{t-i}+E C M_{t-1}+\mu_{t} . .(5)
\end{aligned}
$$




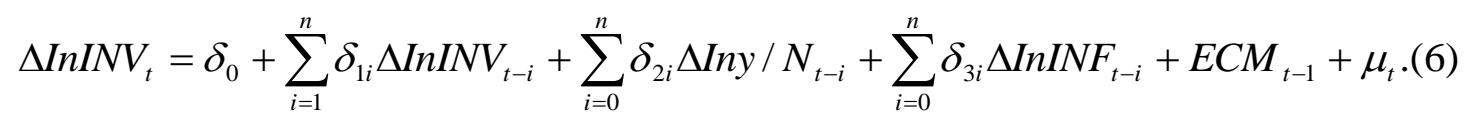

Where $\mathrm{ECM}_{\mathrm{t}-1}=$ the lagged error-correction term obtained from the long-run equilibrium relationship.

The annual data used in this study, cover the period 1972-2009, and are obtained from the International Financial Statistics (IFS) Yearbook (2009) and the World Development Indicators (2010).

The direction of the causality between INF, y/N and INV can be determined from equations (4), (5) and (6) - using the F-statistic and the lagged error-correction term. The " $\mathrm{t}$ " statistic on the coefficient of the lagged errorcorrection term represents the long-run causal relationship, while the F-statistic on the explanatory variables represents the short-run causal effect (see also Odhiambo, 2008; Narayan and Smyth, 2006). It is also worth noting that even though the error-correction term has been incorporated in all the equations (4) - (6), only equations where the null hypothesis of no cointegration is rejected, will be estimated with an error-correction term (see Narayan and Smyth, 2006; Morley, 2006; Odhiambo, 2009a).

\subsection{Empirical Analysis}

\subsubsection{Stationarity Tests}

The stationarity tests of $y / N$, INF and INV were conducted in levels and on first difference. The results of the stationarity tests in levels (not presented here) show that on the whole, the variables are non-stationary in levels. Consequently, the variables were differenced once, in order to perform stationarity tests on differenced variables. The results of the stationarity tests on differenced variables are presented in Table 1.

Table 1: Stationarity Tests of Variables on first Difference

\begin{tabular}{|c|l|l|}
\hline Variable & No Trend & Trend \\
\hline \multicolumn{3}{|c|}{ Phillips-Perron (PP) Test } \\
\hline y/N & $-3.642917 * * *$ & $-3.553847 * *$ \\
\hline INF & $-6.601479 * * *$ & $-6.582375 * * *$ \\
\hline INV & $-9.708952 * * *$ & $-9.588419 * * *$ \\
\hline \multicolumn{3}{|c|}{ Dickey-Fuller - GLS Test } \\
\hline y/N & $-2.825841 * * *$ & $-3.256867 * *$ \\
\hline INF & $-2.996625 * * *$ & $-6.529833^{*} * *$ \\
\hline INV & $-9.729078 * *$ & $-9.815371 * * *$ \\
\hline
\end{tabular}

Note:

1)The truncation lag for the PP tests is based on Newey and West (1987) bandwidth.

2) $* * *$ denotes $1 \%$ level of significance.

3) Critical values for Dickey-Fuller GLS test are based on Elliot-Rothenberg-Stock (1996, Table 1).

The results reported in Table 1 show that all the three variables are stationary after being differenced once. This, therefore, shows that the ARDL-bounds testing approach can now be used - because none of the variables is integrated of order two [I(2)] or higher.

\subsubsection{Bounds Test for Cointegration}

The first step of the ARDL-bounds testing approach involves obtaining the order of lags on the first differenced variables in equations (1) - (3) from the unrestricted models - using the Akaike Information Criterion (AIC) and the Schwartz Bayesian Criterion (SBC). The results of the AIC and SBC tests (not reported here) show that the optimal lag of $\mathrm{y} / \mathrm{N}$ and INV equations is two, while in the case of INF equation, the optimal lag is lag 3 . The second step involves applying the bounds F-test to equations (1) - (3) in order to establish whether a long-run relationship exists between $y / \mathrm{N}, \mathrm{INF}$ and INV. The results of the bounds test are reported in Table 2. 
Table 2: Bounds F-test for Cointegration

\begin{tabular}{|c|c|c|c|c|c|c|}
\hline Dependent variable & \multicolumn{3}{|c|}{ Function } & \multicolumn{3}{|c|}{ F-test statistic } \\
\hline$\Delta \operatorname{Iny} / \mathrm{N}_{\mathrm{t}}$ & \multicolumn{3}{|c|}{$\mathrm{y} / \mathrm{N}(\mathrm{INF}, \mathrm{INV})$} & \multicolumn{3}{|c|}{$6.526 * * *$} \\
\hline$\Delta \operatorname{InINF}_{\mathrm{t}}$ & \multicolumn{3}{|c|}{$\mathrm{INF}(\mathrm{y} / \mathrm{N}, \mathrm{INV})$} & \multicolumn{3}{|c|}{2.500} \\
\hline$\Delta \operatorname{InINV}_{\mathrm{t}}$ & \multicolumn{3}{|c|}{ INV $(\mathrm{y} / \mathrm{N}, \mathrm{INF})$} & \multicolumn{3}{|c|}{1.712} \\
\hline \multicolumn{7}{|c|}{ Asymptotic Critical Values } \\
\hline & \multicolumn{2}{|c|}{$1 \%$} & \multicolumn{2}{|c|}{$5 \%$} & \multicolumn{2}{|c|}{$10 \%$} \\
\hline & $\mathrm{I}(0)$ & $\mathrm{I}(1)$ & $\mathrm{I}(0)$ & $\mathrm{I}(1)$ & $\mathrm{I}(0)$ & $\mathrm{I}(1)$ \\
\hline $\begin{array}{l}\text { Pesaran et al (2001), p. 300, } \\
\text { Table CI(ii) Case II }\end{array}$ & 4.13 & 5.00 & 3.10 & 3.87 & 2.63 & 3.35 \\
\hline
\end{tabular}

Note: $* * *$ denotes statistical significance at the $1 \%$ level.

The results reported in Table 2 show that there is evidence of cointegration in the $\mathrm{y} / \mathrm{N}$ equation, but not in the INF and INV equations. This is supported by the calculated F statistic, which is statistically significant in $\mathrm{y} / \mathrm{N}$ equation, but not in the INF and INV equations.

\subsubsection{Analysis of Granger-causality Test}

Having confirmed the existence of a long-run relationship between $y / N$, INF and INV in section 4.4.2, the next step is to examine the direction of causality between the three variables. The results of these causality tests are reported in Table 3.

Table 3: Granger non-causality test

\begin{tabular}{|c|c|c|c|c|}
\hline \multicolumn{4}{|c|}{ F-statistics [P-value] } & t - statistics \\
\hline Dependent variable & $\Delta \mathbf{I n y} / \mathbf{N}_{\mathbf{t}}$ & $\Delta \mathbf{I n I N F}_{\mathbf{t}}$ & $\Delta \mathbf{I n I N V}_{\mathbf{t}}$ & $\mathbf{E C M}_{\mathbf{t}-1}$ \\
\hline$\Delta \mathbf{I n y} / \mathbf{N}_{\mathbf{t}}$ & - & $6.317[0.0008]^{* * *}$ & $5.647[0.0041]^{* * *}$ & $-0.826^{* * *}$ \\
& & - & & {$[-3.074]$} \\
\hline$\Delta \mathbf{I n I N F}_{\mathbf{t}}$ & $1.725[0.2577]$ & $2.127[0.1553]$ & $6.944[0.0005]^{* * *}$ & \\
\hline$\Delta \mathbf{I n I N V}_{\mathbf{t}}$ & $5.345[0.0051]^{* * *}$ & - & - \\
\hline
\end{tabular}

The empirical results reported in Table 3 show that there is a short-run and long-run unidirectional causal flow from inflation to economic growth in Tanzania, but not vice versa. The short-run causality is supported by the corresponding F-statistic in the $\mathrm{y} / \mathrm{N}$ equation, which is statistically significant, while the long-run causality is supported by the lagged error-correction term, which is found to be negative and statistically significant in the $\mathrm{y} / \mathrm{N}$ equation. The results also show that there is a uni-directional causal flow from investment to economic growth although there is a feedback short-run causal flow from economic growth to investment. Other results show that a unidirectional causal flow from investment to inflation could only be established in the short run.

\section{CONCLUSION}

This paper has examined the causal relationship between inflation and economic growth - using a multivariate model. Specifically, the study incorporates investment in the bivariate setting between inflation and economic growth - thereby, creating a simple trivariate model. The motivation for including investment in the model is informed by the theoretical link between investment and economic growth on the one hand, and that of investment and inflation, on the other hand. Previous studies on this subject have concentrated mainly on Asian and Latin American countries. Very few studies have been conducted in sub-Saharan African countries. Using the ARDL-bounds testing approach, the study finds that there is a unique cointegrating relationship between inflation, investment and economic growth. The study also finds that there is a distinct unidirectional causal flow from inflation to economic growth, without any feedback relationship. This applies irrespective of whether the tests are conducted in the short run or in the long run. Other results show that there is: i) A short-run and long-run causal flow from investment to economic growth; ii) a short-run causal flow from economic growth to investment; and iii) a short-run causal flow from investment to inflation. 


\section{AUTHOR INFORMATION}

Prof Nicholas M Odhiambo is currently working as Professor of Economics and Chair of Growth, Poverty and Policy Modelling (GPPM) Research flagship at the University of South Africa (UNISA). He is an NRF-rated researcher, and has published more than 50 articles in 30 recognised journals. He holds a $\mathrm{PhD}$ (Economics) degree from Stellenbosch University (South Africa) and a Masters degree in Economics from the University of Dar-essalaam (Tanzania). E-mail: Odhianm@unisa.ac.za

\section{REFERENCES}

1. Bank of Tanzania (Annual Report), Various Issues.

2. Barro, R.J., 1996, "Inflation and Growth", Federal Reserve Bank of St. Louis 78, pp.153-169.

3. Bruno, M. and Easterly, W., 1998, "Inflation Crisis and Long-run Growth", Journal of Monetary Economics 41, pp. 3-26.

4. Burdekin, R.C.K., Goodwin, T., Salamun, S., and Willett, T.D.(1994), "The Effects of Inflation on Economic Growth in Industrial and Developing Countries: Is There a Difference?", Applied Economics Letters 1, 175-177.

5. Elliot, G., Rothenberg, T., Stock J. (1996), "Efficient Tests for An Autoregressive Unit Root", Econometrica 64, 813-36.

6. Fischer, S., 1993, "The Role of Macroeconomic Factors in Growth", Journal of Monetary Economics 32, pp. 485-512.

7. $\quad$ Hollerstein, R. (1997), “The Impact of Inflation”, Regional Review, Volume 7, Number 1.

8. International Financial Statistics Yearbook, IMF, 2009.

9. Keynes, J.M. (1936), The General Theory of Employment, Interest and Money, London, Harcourt Brace.

10. Morley, B. (2006), "Causality Between Economic Growth and Migration: An ARDL Bounds Testing Approach", Economics Letters 90, 72-76.

11. Narayan, P.K. and Smyth, R. (2006), "Higher Education, Real Income and Real Investment in China: Evidence From Granger Causality Tests", Education Economics 14, 107-125.

12. Narayan, P.K. and Smyth, R. (2008), "Energy Consumption and Real GDP in G7 Countries: New Evidence From Panel Cointegration With Structural Breaks", Energy Economics 30, 2331-2341.

13. Newey, W.K. and West, K.D (1987), “A Simple, Positive Semi-Definite, Heteroskedasticity and Autocorrelation Consistent Covariance Matrix", Econometrica 55: 703-8.

14. Odhiambo, N.M. (2008), "Financial Depth, Savings and Economic Growth in Kenya: A Dynamic Causal Linkage", Economic Modelling 25(4), 704-713.

15. Odhiambo, NM (2009a), "Finance-Growth-Poverty Nexus in South Africa", The Journal of SocioEconomics 38(2): 320-325.

16. Odhiambo N.M. (2009b), "Interest Rate Reforms, Financial Deepening and Economic Growth in Kenya: An Empirical Investigation", The Journal of Developing Areas 34(1): 295-313.

17. Pesaran, M., Pesaran, B., 1997. Working with Microfit 4.0: Interactive economic analysis, Oxford University Press, Oxford.

18. Pesaran, M., Shin, Y. and Smith, R. (2001), "Bounds Testing Approaches to the Analysis of Level Relationships", Journal of Applied Econometrics 16, 289-326.

19. Rousseau, P.P. and Wachtel, P. (2002), "Inflation Thresholds and the Finance-Growth Nexus", Journal of International Money and Finance 21, pp. 777-793.

20. SADC (2011), "Financial Systems - Tanzania", Committee of Central Bank Governors.

21. World Bank (2007), African Development indicators, various issues to 2009, Washington DC

22. World Bank (2010), African Development indicators, various issues to 2009, Washington DC 


\section{APPENDIX - SELECTED STATISTICS}

\begin{tabular}{cccc} 
Appendix 1 & & & \\
\hline \hline Year & GDP per capita (constant LCU) & GDP growth (annual \%) & GDP per capita growth (annual \%) \\
\hline \hline 1997 & 244770 & 4 & 1 \\
1998 & 247523 & 4 & 2 \\
1999 & 253092 & 5 & 2 \\
2000 & 258918 & 5 & 3 \\
2001 & 267436 & 6 & 4 \\
2002 & 279171 & 7 & 4 \\
2003 & 290401 & 7 & 5 \\
2004 & 304782 & 8 & 4 \\
2005 & 318364 & 7 & 4 \\
2006 & 330438 & 7 & 4 \\
2007 & 344140 & 7 & 3 \\
2008 & 359244 & 7 & 4 \\
2009 & 369965 & 6 & 4 \\
2010 & 384467 & 7 & \\
\hline \hline
\end{tabular}

Source: World Development Indicators (2011)

\begin{tabular}{ccc} 
Appendix 2 & & \\
\hline \hline Year & Inflation (consumer prices - annual \%) & Inflation (GDP deflator - annual \%) \\
\hline \hline 1997 & 16 & 21 \\
1998 & 13 & 27 \\
1999 & 8 & 11 \\
2000 & 6 & 8 \\
2001 & 5 & 5 \\
2002 & 5 & 7 \\
2003 & 5 & 8 \\
2004 & 5 & 7 \\
2005 & 5 & 6 \\
2006 & 7 & 5 \\
2007 & 7 & 9 \\
2008 & 10 & 10 \\
2009 & 12 & 7 \\
2010 & 6 & 8 \\
\hline \hline
\end{tabular}

Source: World Development Indicators (2011)

\begin{tabular}{ccc} 
Appendix 3 & & \\
\hline \hline Year & Gross fixed capital formation (\% of GDP) & Gross fixed capital formation (annual \% growth) \\
\hline \hline 1997 & 15 & 0 \\
1998 & 20 & 14 \\
1999 & 17 & 6 \\
2000 & 16 & 6 \\
2001 & 17 & 12 \\
2002 & 19 & 8 \\
2003 & 20 & 14 \\
2004 & 21 & 10 \\
2005 & 23 & 19 \\
2006 & 24 & 16 \\
2007 & 25 & 15 \\
2008 & 26 & 8 \\
2009 & 29 & 10 \\
2010 & 30 & 8 \\
\hline \hline
\end{tabular}

Source: World Development Indicators (2011) 